\title{
Nutritive value of sugarcane silages with different bacterial additives and fermentation periods
}

\section{Valor nutritivo de silagens de cana-de-açúcar com diferentes aditivos bacterianos e periodos de fermentação}

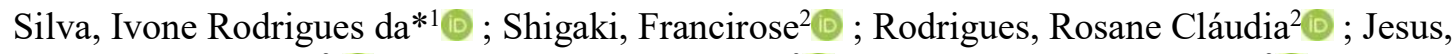
Ana Paula Ribeiro ${ }^{2}$ (1) ; Costa, Clésio dos Santos ${ }^{3}{ }^{\circ}$; Araújo, Ricardo Alves de ${ }^{2}{ }^{\circ}$; Sousa Santos, Francisco Naysson ${ }^{4}$; Mendes, Sanayra da Silva ${ }^{2}{ }^{\circ}$

${ }^{1}$ Universidade Federal do Piaui, Departamento de Zootecnia,Ininga, Teresina 64049-550, PIBraszil

${ }^{2}$ Universidade Federal do Maranhão, Deparatemento de Zootecnia, Rodovia BR-222, S/N , São Luís -65085-580, MA-Brasil

${ }^{3}$ Universidade Federal do Ceará, Av. Mister Hull, 572, Bloco 808, 60356-001, Fortaleza, Ceará, Brazil

${ }^{4}$ Universidade Federal da Paraíba, Departamento de Zootecnia, Areia, Paraíba, Brazil

*Corresponding author: ivonerodrigues10@hotmail.com

\section{ABSTRACT}

The objective of this study was to evaluate the nutritive value of sugarcane silage with or without inoculation with $P$. acidipropionici or L. buchneri, over three fermentation periods. The experimental design was completely randomized in a $3 \mathrm{x}$ 3 inoculant by fermentation period factorial arrangement (without inoculant, inoculant 1, inoculant 2; $\mathrm{x}$ three fermentation periods, $10,60,90$ days). Values of $\mathrm{pH}$, dry matter (DM), crude protein (CP), neutral detergent fiber (NDF), acid detergent fiber (ADF), hemicellulose (HEM) and lignin were determined and in situ DM degradability profiles were modelled for parameters $a, b$ and $c$, potential degradation (A) and effective degradability (ED). The 90 day fermentation yielded a lower $\mathrm{pH}$ for both inoculants. There was an interaction between inoculant and fermentation period $(\mathrm{P}<0.05)$ for $\mathrm{DM}$ content, with a reduction in silage DM without the additive at 90 days. The CP, HEM, ADF and lignin contents of sugarcane were not influenced by the treatments. The addition of $P$. acidipropionici provided the lowest NDF content at 10 days and presented a higher fraction $a$, potential degradation and ED. At 60 days, there was no variation in soluble fraction, the control silage showed a higher fraction $b$, higher potential degradation and ED. At 90 days of fermentation, L. buchneri silages presented a higher fraction $a$, degradation rate and $\mathrm{DE}$ and a higher $b$ value was obtained in the silage without inoculant. Inoculants are effective in maintaining the silage DM content and nutritional value during prolonged fermentation periods.

Keyword: dry matter, inoculant, ruminal degradation

\section{RESUMO}

Objetivou-se avaliar o valor nutritivo de silagens de cana-de-açúcar com ou sem inoculante, em diferentes períodos de fermentação. O delineamento experimental foi o inteiramente casualizado em arranjo fatorial 3 × 3 (sem inoculante, inoculante $1 \mathrm{e}$ inoculante $2 \times$ três períodos de fermentação, 10; 60 e 90 dias). Analisou-se $\mathrm{pH}$, matéria seca (MS), proteína bruta (PB), fibra em detergente neutro (FDN), fibra em detergente ácido (FDA), hemicelulose (HEM) e lignina; e degradabilidade in situ da MS, quanto aos parâmetros $a, b$ e $c$, degradação potencial (A) e degradabilidade efetiva (DE). Houve diferença para o $\mathrm{pH}, \mathrm{o}$ período de 90 dias apresentou menor média para ambos inoculantes. Houve interação 
inoculante $\mathrm{x}$ período de fermentação $(\mathrm{P}<0,05)$ para o teor de MS, com redução na silagem sem aditivo aos 90 dias. Os teores de PB, HEM, FDA e lignina não foram influenciados pelos tratamentos. A bactéria $P$. acidipropionici proporcionou menor teor de FDN aos 10 dias e apresentaram maior fração $a$, degradação potencial e DE. Aos 60 dias não houve variação na fração solúvel, a silagem controle apresentou maior fração $b$, maior degradação potencial e DE. Aos 90 dias de fermentação, as silagens com $L$. buchneri apresentaram maior fração $a$, taxa de degradação e DE e obteve-se maior valor de $b$ na silagem sem inoculante. Os inoculantes são eficientes em manter os teores de MS das silagens durante períodos prolongados de fermentação e manter o valor nutricional do material ensilado.

Palavras-chave: degradação ruminal, inoculante, matéria seca 


\section{INTRODUCTION}

Sugarcane (Saccharum officinarum L.) is a forage alternative for ruminants during the dry season and is often used in natural form through daily manual harvests (Schmidt et al., 2011). Inherent in this form of harvest is the need for hiring labor for cutting, shredding, chopping, loading and frequent transport, which all increase costs. An alternative is to ensile the sugarcane to be able to use it more cost-effectively.

The principle of ensiling is the transformation of soluble carbohydrates in the substrate into lactic acid during fermentation by lactic acid bacteria in an anaerobic environment. However, the chemical characteristics of the soluble carbohydrates in sugarcane favor alcoholic fermentation, which is performed by yeasts, and entails the loss of dry matter and the concomitant loss in nutritive value of the ensiled material (Bernardes et al., 2007).

The presence of sucrose, the main carbohydrate found in sugarcane, favors the proliferation of the yeast population during fermentation, which converts sugars to ethanol and $\mathrm{CO}_{2}$. The ethanol decreases the amount of sugar available to lactic acid bacteria and, thus, under aerobic conditions, many yeast species degrade lactic acid, causing an increase in silage $\mathrm{pH}$ (McDonald, 1991).

To circumvent these problems, the use of biological additives has been studied. Heterolactic bacteria have been gaining prominence because they are producers of acetic and propionic acids, as well as lactic acid, which together have the ability to reduce yeast and fungal activity during the fermentation phase of silage. The Lactobacillus buchneri species has shown promising results in sugarcane silages by inhibiting yeast growth and increasing aerobic stability (Schmidt et al., 2014). Another group of microorganisms that has been studied is the genus Propionibacterium, which characteristically produces propionic acid. However, according to Pedroso et al. (2011), the results with the application of these additives have been inconsistent and with little information on the resulting nutritional value of sugarcane silages. Therefore, in addition to evaluating these bacteria, it is important to monitor the action of inoculants during the fermentation process (Carvalho et al., 2014). Thus, the objective of this study was to evaluate the nutritive value of sugarcane silages with or without the addition of bacterial inoculants over different fermentation periods.

\section{MATERIAL AND METHODS}

The experiment was carried out in the Forage Industry Sector of the Center for Agricultural and Environmental Sciences of the Federal University of Maranhão (CCAA / UFMA), in Chapadinha, MA, region of Baixo Parnaíba, Brazil $\left(03^{\circ} 44^{\prime} 33^{\prime \prime} \mathrm{S}, 43^{\circ} 21^{\prime} 21^{\prime \prime}\right.$ $\mathrm{W})$. The climate, according to the Köppen climate classification, is hot, humid and tropical, with an annual average temperature of over $27{ }^{\circ} \mathrm{C}$ and cumulative annual rainfall of $1,835 \mathrm{~mm}$, with periods of rain between January and June and dry from July to December.

Two bacterial inoculants were evaluated: Propionibacterium acidipropionici and Lactobacillus buchneri in different fermentation periods of 10,60 and 90 days in a completely randomized design (CRD), in a $3 \times 3$ factorial arrangement (uninoculated silage, inoculated with Propionibacterium acidipropionici, inoculated with Lactobacillus buchneri; over three fermentation periods), with five replications per treatment. $L$. 
buchneri was applied to the sugarcane to achieve an inoculation dose of $5 \times 10^{4}$ $\mathrm{cfu} / \mathrm{g}$ of forage and P. acidipropionici at a dose of $1 \times 10^{5} \mathrm{cfu} / \mathrm{g}$ of forage. These doses were recommended by the manufacturer to ensure optimal fermentation of the silage, in this particular case, for sugarcane.

The sugarcane variety used was SP 813250 , at 12 months of growth, harvested manually and without burning. The material was ground to 1.0 to 2.0 $\mathrm{mm}$ particles in a forage machine on the same day of harvest. The material was separated into 3 parts, one for silage without additives (control) and the other two for the application of additives.

For ensilation, PVC mini silos were used $(0.10 \mathrm{~m}$ in diameter and $0.25 \mathrm{~m}$ high), with Busen-type valves to allow the escape of fermentation gases. The compaction was performed with the aid of PVC-coated concrete sockets, thus providing a specific mass with density of $750 \mathrm{~kg}$ green material $/ \mathrm{m}^{3}$. After compaction, the silos were sealed and weighed.

The mini silos were opened after the prescribed days of fermentation (10, 60 and 90 days). The silage was homogenized, and two samples of the ensiled material were collected. One sample was used to determine the $\mathrm{pH}$, which was performed by diluting nine grams of fresh silage in $60 \mathrm{~mL}$ of distilled water and reading after 30 minutes of rest, as described by Silva \& Queiroz (2002). The second $300 \mathrm{~g}$ sample was dried in a $55{ }^{\circ} \mathrm{C}$ forced-air oven until the sample maintained a constant weight, then milled in a $1 \mathrm{~mm}$ sieve (Willey mill) for further chemical analysis and for the assay of in situ degradability of dry matter (DM).

Nutrient content of the silage was determined by the following methods: dry matter (DM) content for 24 hours in a drying oven at $105{ }^{\circ} \mathrm{C}$, crude protein (CP) (method 988.05; AOAC procedures, 1998), neutral detergent fiber (NDF) and acid detergent fiber (ADF) according to the methodology of Van Soest et al. (1991), and acid detergent lignin was determined by solubilization of cellulose with $72 \%$ sulfuric acid (method 973,18; AOAC, 1998).

Data on the chemical composition of sugarcane at the time of ensiling are described in Table 1.

Table 1. Chemical composition of sugarcane before ensiling

\begin{tabular}{lc}
\hline Parameters & Sugarcane \\
\hline Dry matter (\% of FM) & 26,72 \\
Crupe protein (\% of DM) & 2,13 \\
Neutral detergent fiber (\% of DM) & 65,11 \\
Hemicellulose (\% of DM) & 29,17 \\
Acid detergent fiber (\% of DM) & 35,94 \\
Lignin (\% of DM) & 20,28 \\
\hline
\end{tabular}

Dry matter degradability (DMD) was estimated by the in situ technique using a cross-bred sheep with a live weight of $60 \mathrm{~kg}$, approved by the Ethics and 
Biosafety Committee under the number: (23115.011059 / 2015-26). This procedure was suggested by Tomich and Sampaio (2004). $4 \mathrm{~g}$ of the ground sample was placed in nylon bags measuring $12 \times 8 \mathrm{~cm}$ with pores of $50 \mu \mathrm{m}$ in diameter (NOCEK, 1988). For the degradability test, a completely randomized design with repeated measures was used. Repeated measures were the incubation periods of $6,24,72$ and 96 hours.

To determine the disappearance of the material at time zero, the bags were kept in a water bath for 1 hour at a temperature of $39^{\circ} \mathrm{C}$ (Brito et al., 2007). After this time, the bags were removed from the water bath and were washed along with the ruminal incubation bags and were kept in a forced-air oven at 55 ${ }^{\circ} \mathrm{C}$ for 48 hours.

The percentage of dry matter disappearance (DMS) for each time was calculated by the proportion of food that disappeared from the bags after ruminal incubation. To evaluate the DMS parameters, the model of Orskov \& McDonald (1979), subsequently adapted by Sampaio (1988), was used:

$$
\text { Deg }=\text { A - B * (- ct), }
$$

Where A - corresponds to the potential degradation of the incubated material when time is not a limiting factor; B parameter without biological value, that is, if there was no time of colonization, it would correspond to the total to be degraded by microbial action; $\mathrm{c}$ - rate of degradation by fermentative action of $\mathrm{B}$; $\mathrm{t}=$ rumen incubation time in hours.
Once the coefficients A, B and c were calculated, they were applied to the equation proposed by Ørskov and McDonald (1979) to calculate the effective degradability:

$$
\mathrm{DE}=\mathrm{a}^{\prime}+\left(\mathrm{b}^{\prime} * \mathrm{C}\right) /(\mathrm{C}+\mathrm{k}) \text {, }
$$

Where $\mathrm{a}^{\prime}=\%$ disappearance at time zero (Average); $b^{\prime}=A-a^{\prime} ; C=$ constant rate of degradation; $\mathrm{K}$ = food passage rate, $\mathrm{a}$ digesta to duodenum passage rate of 2,5 and $8 \%$ per hour was assumed.

The data were subjected to the comparison of means by the SNK test at $5 \%$ probability by the PROC GLM procedure of the SAS statistical software (2002). The degradation parameters $a, b$ and $c$ and the in situ degradation curves were determined according to the GaussNewton method by the SAS PROC NLIN procedure (2002).

\section{RESULTS AND DISCUSSION}

There was no interaction between the inoculants tested and fermentation periods $(\mathrm{P}>0.05)$ on silage $\mathrm{pH}$. There was significant difference $(\mathrm{P}<0.05)$ only between fermentation periods (Table 2). Lower $\mathrm{pH}$ values were measured in the 90 day fermentation for all silages, with an average of 3.29. Properly fermented silages have a $\mathrm{pH}$ of 3.8 to 4.2 , a range that restricts the action of proteolytic enzymes on the ensiled mass, inhibiting the development of bacteria of the genus Clostridium (Muck, 1988). However, many yeasts are able to grow at $\mathrm{pH} 3.5$, which is below the $\mathrm{pH}$ of most silages (Muck, 2010), but is more frequent in sugarcane silage. 
Table 2. Average $\mathrm{pH}$ values of sugarcane silage with different bacterial inoculants and fermentation periods

\begin{tabular}{|c|c|c|c|c|c|c|c|}
\hline \multicolumn{8}{|c|}{$\mathrm{pH}$} \\
\hline \multirow{2}{*}{ Inoculant } & \multicolumn{3}{|c|}{ Fermentation period } & \multirow{2}{*}{ Average } & \multicolumn{3}{|c|}{ p-value } \\
\hline & 10 & 60 & 90 & & $\mathrm{FP}^{3}$ & $\mathrm{I}^{4}$ & $\mathrm{FP}^{*} \mathrm{I}^{5}$ \\
\hline Control & 3,56 & 3,55 & 3,27 & $3,46 \mathrm{~A}$ & \multirow{4}{*}{$<0,0001$} & \multirow{4}{*}{0,2963} & \multirow{4}{*}{0,0523} \\
\hline Buch $^{1}$ & 3,45 & 3,51 & 3,33 & $3,43 \mathrm{~A}$ & & & \\
\hline Prop $^{2}$ & 3,48 & 3,54 & 3,27 & $3,43 \mathrm{~A}$ & & & \\
\hline Average & $3,50 \mathrm{a}$ & $3,53 \mathrm{a}$ & $3,29 b$ & & & & \\
\hline CV $(\%)$ & & & & & & & \\
\hline
\end{tabular}

Averages followed by similar capital letters in columns and lowercase letters in rows do not differ significantly from each other by the SNK test at $\mathrm{P}<0.05$. 1 L. buchneri; 2 P. acidipropionici; 3 Fermentation periods; 4 Inoculant; 5 Interaction effect between fermentation period and inoculant.

Valeriano et al. (2009) observed a $\mathrm{pH}$ value of 3.53 in sugarcane silages inoculated with L. buchneri after 90 days of fermentation. The $\mathrm{pH}$ of 3.29 in this study and that of Valeriano et al. (2009) is characteristic of alcoholic fermentation, which occurs in sugarcane because of the high levels of soluble carbohydrates.

An interaction effect $(\mathrm{P}<0.05)$ was observed for DM content as a function of fermentation periods and additives (Table 3). The silage without inoculant produced a higher DM content over the fermentation periods of 10 and 30 days, while after 90 days, it was observed that the DM content of silage with $P$. acidipropionici and the control silage did not differ significantly. Between fermentation periods, it was observed that there was a reduction in dry matter content for the 90-day fermentation period in control silage, which was not observed in inoculated silages. The reduction in DM content of the control silage can probably be attributed to the loss of soluble carbohydrates during the fermentation process (Fortaleza et al., 2012), caused by excessive yeast overgrowth. This contribute to a significant loss of DM, because the metabolic pathway in the production of alcohols is very inefficient (McDonald et al., 1991). 
Table 3. Average contents of dry matter (DM) and crude protein (CP) of sugarcane silage with different bacterial inoculants and fermentation periods

\begin{tabular}{|c|c|c|c|c|c|c|c|}
\hline \multicolumn{8}{|c|}{ Dry matter (DM) } \\
\hline \multirow{2}{*}{ Inoculant } & \multicolumn{3}{|c|}{ Fermentation periods } & \multirow{2}{*}{ Average } & \multicolumn{3}{|c|}{ p-value } \\
\hline & 10 & 60 & 90 & & $\mathrm{FP}^{3}$ & $\mathrm{I}^{4}$ & $\mathrm{FP} \times \mathrm{I}^{5}$ \\
\hline Control & $28,06 \mathrm{Aa}$ & $28,33 \mathrm{Aa}$ & $25,03 \mathrm{Ab}$ & 27,14 & \multirow{4}{*}{0,0061} & \multirow{4}{*}{0,0001} & \multirow{4}{*}{0,0005} \\
\hline Buch $^{1}$ & $25,79 \mathrm{Ba}$ & $25,55 \mathrm{Ba}$ & $23,47 \mathrm{Ba}$ & 24,84 & & & \\
\hline Prob $^{2}$ & $25,69 \mathrm{Ba}$ & $23,75 \mathrm{Ba}$ & $26,18 \mathrm{Aa}$ & 25,21 & & & \\
\hline Average & 26,51 & 25,77 & 24,9 & & & & \\
\hline $\mathrm{CV}(\%)$ & \multicolumn{7}{|c|}{4,38} \\
\hline \multicolumn{8}{|c|}{ Crude protein $(\mathrm{CP})$} \\
\hline Control & 2,32 & 2,11 & 2,70 & $2,38 \mathrm{~A}$ & \multirow{4}{*}{0,0682} & \multirow{4}{*}{0,3521} & \multirow{4}{*}{0,076} \\
\hline Buch & 2,50 & 2,17 & 2,20 & $2,29 \mathrm{~A}$ & & & \\
\hline Prob & 2,23 & 2,20 & 2,28 & $2,23 \mathrm{~A}$ & & & \\
\hline Average & $2,35 a$ & $2,16 a$ & $2,39 a$ & & & & \\
\hline CV (\%) & & & & 9,72 & & & \\
\hline
\end{tabular}

Averages followed by similar capital letters in columns and lowercase letters in rows do not differ significantly from each other by the SNK test at $\mathrm{P}<0.05 .1$ L. buchneri; 2 P. acidipropionici; 3 Fermentation periods; 4 Inoculant; 5 Interaction effect between fermentation period and inoculant.

The average DM content for L. buchneri containing silages $(24.84 \%)$ was close to the $23.35 \%$ DM value observed by Balieiro et al. (2009). Siqueira et al. (2011) found values of $24.8 \%$ and 25.9 $\%$ DM for silage containing L. buchneri and silages without inoculants, respectively. There was no significant difference $(\mathrm{P}>0.05)$ for crude protein contents. The CP content of inoculated silages was similar to that observed in sugarcane before ensiling $(2.13 \%)$ and produced no significant differences $(\mathrm{P}>$ 0.05 ) between the treatment groups.
Among the evaluated structural components (Table 4), only NDF was different between the evaluated silages $(\mathrm{P}>0.05)$. P. acidipropionici silages showed a lower NDF content at 10 days of fermentation. The applied dose of $P$. acidipropionici may not have been sufficient to prevent alcoholic fermentation over long periods, because the NDF content increased over the longer periods of fermentation (60 and 90 days). 
Table 4. Average contents of neutral detergent fiber (NDF), hemicellulose (HEM), acid detergent fiber (ADF) of sugarcane silage with different bacterial inoculants and fermentation periods

\begin{tabular}{|c|c|c|c|c|c|c|c|}
\hline \multicolumn{8}{|c|}{ Neutral detergent fiber } \\
\hline \multirow[t]{2}{*}{ Inoculant } & \multicolumn{3}{|c|}{ Fermentation periods } & \multirow[t]{2}{*}{ Average } & \multicolumn{3}{|c|}{ p-value } \\
\hline & 10 & 60 & 90 & & $\mathrm{PF}^{3}$ & $\mathrm{I}^{4}$ & ${\mathrm{PF} \times \mathrm{I}^{5}}^{5}$ \\
\hline Control & $74,05 \mathrm{Aa}$ & $75,67 \mathrm{Aa}$ & $76,7 \mathrm{Aa}$ & 75,47 & \multirow{4}{*}{$<0,0001$} & \multirow{4}{*}{0,0263} & \multirow{4}{*}{0,01} \\
\hline Buch $^{1}$ & $73,6 \mathrm{Aa}$ & $75,91 \mathrm{Aa}$ & $76,32 \mathrm{Aa}$ & 75,28 & & & \\
\hline Prob $^{2}$ & $69,8 \mathrm{Bb}$ & $76,22 \mathrm{Aa}$ & $75,99 \mathrm{Aa}$ & 74,00 & & & \\
\hline Average & 72,48 & 75,93 & 76,34 & & & & \\
\hline $\mathrm{CV}(\%)$ & \multicolumn{7}{|c|}{1,80} \\
\hline \multicolumn{8}{|c|}{ Hemicellulose } \\
\hline Controle & 31,74 & 31,74 & 30,00 & $31,16 \mathrm{~A}$ & \multirow{4}{*}{0,2195} & \multirow{4}{*}{0,0588} & \multirow{4}{*}{0,2184} \\
\hline Buch & 27,45 & 32,13 & 34,15 & $31,74 \mathrm{~A}$ & & & \\
\hline Prob & 28,95 & 30,53 & 28,63 & $28,87 \mathrm{~A}$ & & & \\
\hline Average & $29,38 \mathrm{a}$ & $31,47 \mathrm{a}$ & $30,93 a$ & & & & \\
\hline $\mathrm{CV}(\%)$ & \multicolumn{7}{|c|}{9,70} \\
\hline \multicolumn{8}{|c|}{ Acid detergent fiber } \\
\hline Control & 42,32 & 43,93 & 46,69 & $44,31 \mathrm{~A}$ & \multirow{4}{*}{0,2709} & \multirow{4}{*}{0,5256} & \multirow{4}{*}{0,2219} \\
\hline Buch & 44,65 & 43,78 & 42,17 & $43,53 \mathrm{~A}$ & & & \\
\hline Prob & 42,35 & 45,70 & 47,36 & $45,14 \mathrm{~A}$ & & & \\
\hline Average & $43,11 \mathrm{a}$ & $44,47 \mathrm{a}$ & $45,41 \mathrm{a}$ & & & & \\
\hline CV $(\%)$ & \multicolumn{7}{|c|}{7,72} \\
\hline \multicolumn{8}{|c|}{ Lignin } \\
\hline Control & 16,18 & 20,94 & 21,32 & $19,48 \mathrm{~A}$ & \multirow{4}{*}{0,0026} & \multirow{4}{*}{0,4805} & \multirow{4}{*}{0,5716} \\
\hline Buch & 17,71 & 18,82 & 24,03 & $20,19 \mathrm{~A}$ & & & \\
\hline Prob & 18,19 & 22,57 & 22,66 & $22,67 \mathrm{~A}$ & & & \\
\hline Average & $17,36 \mathrm{~b}$ & $20,78 \mathrm{a}$ & $22,57 \mathrm{a}$ & & & & \\
\hline CV $(\%)$ & & & & 16,47 & & & \\
\hline
\end{tabular}

Averages followed by similar capital letters in columns and lowercase letters in rows do not differ significantly from each other by the SNK test at $\mathrm{P}<0.05 .1$ L. buchneri; 2 P. acidipropionici; 3 Fermentation periods; 4 Inoculant; 5 Interaction effect between fermentation period and inoculant.

This may have been due to the low $\mathrm{pH}$ of silages (Table 1), as $P$. acidipropionici bacteria are intolerant to acidic conditions (at a value close to or below 4). Therefore, a silage $\mathrm{pH}$ below 4.2 may have inhibited bacterial growth and propionic acid production (Michel et al., 2017).
Siqueira et al. (2011) evaluated fresh sugarcane silage (without burning) and burned with calcium oxide $(\mathrm{CaO})$ and / or L. buchneri, and observed an NDF content of $75.9 \%$ for sugarcane silage with added L. buchneri at 60 days of fermentation, which was higher than the content of the material before ensiling. This anomaly was also observed in the 
present study, where sugarcane had a lower NDF content before ensiling (Table 1). The aforementioned authors state that fermentation performed by yeast in an anaerobic environment will produce ethanol, carbon dioxide, water and ATP, generating losses of DM and consequently, proportionally increasing fibrous fractions.

HEM and ADF contents increased in $L$. buchneri silages by $8.09 \%$ and $17.43 \%$, respectively, in relation to pre-ensiled sugarcane (Table 1). This was also observed by Mendes et al. (2008) when working with L. buchneri silages, which presented $46.3 \%$ of ADF and $23.1 \%$ of HEM, while the fresh material contained $28.9 \%$ and $21.0 \%$ of ADF and HEM, respectively. As with NDF, the increased concentration of ADF and HEM is caused by the loss of soluble carbohydrates during alcoholic fermentation, producing increased levels of cell wall constituents.

Lignin content was not influenced by inoculants $(\mathrm{P}>0.05)$. There was variation only between fermentation periods $(\mathrm{P}<0.05)$, where, at 10 days of fermentation there was a lower lignin content. The high levels of lignin observed in this study were due to the accumulation of dead material that the sugarcane presented at the time of ensiling, since no shredding was performed. Siqueira et al. (2011) evaluated fresh and burnt sugarcane silage and observed a $28 \%$ reduction in lignin content for burnt sugarcane before ensiling, since bagasse is a fraction with high concentrations of NDF, ADF and lignin.

At 10 days of fermentation, silages inoculated with $P$. acidipropionici bacteria presented higher water soluble fractions (Table 5), with $27.50 \%$, which was $34.18 \%$ and $35.65 \%$ higher than silage without additives and with $L$. buchneri. respectively. The dry matter fraction " $a$ " represents the portion of the food that is readily available to rumen microorganisms (Bezerra et al., 2015). Access of ruminal microbial enzymes to the cell wall results in the reduction of the insoluble fraction, and an increased digestibility (Rocha et al., 2015).

Although silage without inoculant had higher value of fraction $b$ in 10 days, $P$. acidipropionici silages had higher potential degradation and, consequently, higher effective degradability at all passage rates. The highest percentage of ruminal degradation of $P$. acidipropionici silages is due to the lower amount of NDF at 10 days of fermentation (Table 4). 
Table 5. Ruminal degradation parameters $(a, b$ and $c)$, potential degradability (A) and effective degradation (ED) of dry matter at passage rates 2, 5 and $8 \%$ per hour of sugarcane silage with different bacterial inoculants and fermentation periods

\begin{tabular}{cllllllllll}
\hline \multirow{2}{*}{$\begin{array}{c}\text { Fermentation } \\
\text { Days }\end{array}$} & Additive & $a(\%)$ & $b(\%)$ & $c(\% / h)$ & $\mathrm{A}$ & $\mathrm{R}^{2}$ & \multicolumn{4}{c}{\begin{tabular}{c} 
Effective degradation \\
\cline { 7 - 10 }
\end{tabular}} \\
& & & & & & & $2 \% / \mathrm{h}$ & $5 \% / \mathrm{h}$ & $8 \% / \mathrm{h}$ \\
\hline \multirow{3}{*}{10} & Control $^{*} 18,10$ & 67,50 & 0,50 & 85,60 & 96,18 & 31,69 & 24,28 & 22,10 \\
& Buch $^{1}$ & 17,70 & 38,84 & 1,58 & 56,54 & 80,59 & 34,84 & 27,03 & 24,11 \\
& Prob $^{2}$ & 27,50 & 63,58 & 0,52 & 91,08 & 98,61 & 40,56 & 33,46 & 31,36 \\
\hline \multirow{3}{*}{60} & Control & 15,60 & 32,58 & 2,79 & 48,18 & 96,84 & 34,58 & 27,27 & 24,02 \\
& Buch & 15,60 & 30,11 & 2,77 & 45,71 & 95,24 & 33,09 & 26,33 & 23,34 \\
& Prob & 15,20 & 27,61 & 3,16 & 42,81 & 79,04 & 32,11 & 25,89 & 23,02 \\
\hline \multirow{2}{*}{90} & Control & 16,20 & 62,28 & 0,69 & 78,48 & 99,57 & 32,18 & 23,75 & 21,15 \\
& Buch & 21,33 & 40,86 & 1,36 & 62,19 & 97,14 & 37,87 & 30,07 & 27,27 \\
& Prob & 14,80 & 46,65 & 0,96 & 61,45 & 99,31 & 29,89 & 22,29 & 19,78 \\
\hline
\end{tabular}

$\mathrm{a}=$ water soluble fraction; $\mathrm{b}=$ water insoluble fraction, but potentially degradable; $\mathrm{c}=$ fraction degradation rate $\mathrm{b} ; \mathrm{R}^{2}=$ coefficient of determination, $\mathrm{A}=$ potential degradability ${ }^{1}$ L. buchneri; ${ }^{2}$ P. acidipropionici

At 60 days of fermentation there was no difference in soluble fraction between silages. Silage without additives obtained a higher $b$ fraction, higher potential degradability and higher effective degradation for all passage rates. The soluble and insoluble fraction percentages of L. buchneri silages were higher than those found by Rocha et al. (2015), who found in sugarcane silage with L. buchneri at 60 days of fermentation, an $a$ fraction of $17.73 \%$ and $57.43 \%$ potential degradation.

At 90 days of fermentation, L. buchneri silages presented a higher $a$ fraction, A, and $\mathrm{ED}$ at all passage rates, while silage without additives obtained higher values of fraction $b$ and A. Filya et al. (2003) worked with corn, wheat and sorghum silages with added L. buchneri bacteria and homofermentative bacteria and did not observe significant differences in DM degradability values among the inoculated silages.
The low degradation values are related to the high lignin content that the silages presented at 60 and 90 days, given that lignin is negatively related to ruminal degradation. According to Jung \& Deetz (1993), cell wall lignification may limit polysaccharide digestion through the physical impediment caused by lignin polysaccharide binding, which limits the access of fibrolytic enzymes to the reaction center of a specific carbohydrate. Inoculants are efficient in maintaining the silage DM content during prolonged fermentation periods and maintaining the nutritional value of the silage material.

\section{ACKNOWLEDGEMENTS}

To FAPEMA for the granting of the scholarship and to the FOPAMA forage research group. 


\section{REFERENCES}

ASSOCIATION OF OFFICIAL ANALYTICAL CHEMISTS - AOAC. Official methods of analysis. 16th ed. 4th rev. Assoc. Off. Anal. Chem., Arlington, VA. 1998.

BERNARDES, T.F.; REIS, R.A.; SIQUEIRA, G.R.; BERCHIELLI, T.T.; COAN, E.R. M. Avaliação da queima e da adição de milho desintegrado com palha e sabugo na ensilagem de canade-açúcar. Revista Brasileira de Zootecnia, v. 36, p. 269-275, 2007.

BRITO, M.R.; SAMPAIO, A.A.M.; FERNANDES, A.R.M.; HENRIQUE, W.; CATTELAN, J.W.; ROUTMAN, K.S. Degradabilidade in situ e parâmetros ruminais em bovinos alimentados com dietas balanceadas para diferentes ganhos de peso e potenciais de fermentação microbiana.

Revista Brasileira de Zootecnia, v.36, n.5, p.1639-1650, 2007.

BALIEIRO NETO, G.; FERRARI JUNIOR, E.; NOGUEIRA, J. R.; POSSENTI, R.; TADEU, P.V. Perdas fermentativas, composição química, estabilidade aeróbia e digestibilidade aparente de silagem de cana-de açúcar com aditivos químico e microbiano.

Pesquisa Agropecuária Brasileira, v.44, n.6, p. 621-630, 2009.

BEZERRA, H.F.C.; SANTOS, E.M.; OLIVEIRA, J.S.; CARVALHO, G.G.P.; CASSUCE, M.R.; PERAZZO, A.F.; FREITAS, D.S.S.; SANTOS, V.S. Degradabilidade ruminal in situ de silagens de capim-elefante aditivadas com farelo de milho e inoculante da microbiota autóctone. Revista Brasileira de Saúde e Produção Animal, v.16, n.2, p.265-277, 2015.
CARVALHO, B.F.; ÁVILA, C.L.S.; PINTO, J.C.; NERI, J.; SCHWAN, R.F. Microbiological and chemical profile of sugar cane silage fermentation inoculated with wild strains of lactic acid bactéria. Animal Feed Science and Technology, v. 195, p. 1-13, 2014.

FORTALEZA, A.P.S.; SILVA, L.D.F.; ZACKM, E.; BARBERO, R.P.; RIBEIRO, E. L.A.; PEGORARO, M.; SANTOS, L.E.; MIZUBUTI, I.Y. Composição química e degradabilidade ruminal de silagens da canade-açúcar tratada com aditivos químicos e bacteriano. Semina: Ciências

Agrárias, v. 33, suplemento 2, p. 33413352, 2012.

FILYA, I. The effect of Lactobacillus buchneri, with or without homofermentative lactic acid bacteria, on the fermentation, aerobic stability and ruminal degradability of wheat, sorghum and maize silages. Journal of Applied Microbiology. v. 95, p.10801086, 2003.

JUNG, H.G., DEETZ, D.A. Cell wall lignification and degradability. IN: H.G. JUNG., D.R. BUXTON., R.D.

HATIFIELD. et al. (Ed) Forage cell wall structure and digestibility. Madison : American Society of Agronomy, Crop Sci. Society of America, Soil Sci. Society of America, p.315-346, 1993.

MENDES, C.Q.; SUSIN, I.; NUSSIO, L.G.; PIRES, L.V.; RODRIGUES, G.H.; URANO F.S. Efeito do Lactobacillus buchneri na fermentação, estabilidade aeróbia e no valor nutritivo de silagem de cana-de-açúcar. Revista Brasileira de Zootecnia, v.37, n.12, p.2191-2198, 2008. 
MICHEL, P. H. F.; GONCALVES, L. C.; RODRIGUES, J. A. S.; KELLER, K. M.; RAPOSO, V. S.; LIMA, E. M.; SANTOS, F. P. C.; JAYME, D. G. Reensiling and inoculant application with Lactobacillus plantarum and Propionibacterium acidipropionici on sorghum silages. Grass and Forage Science, v. 72, n. 3, p. 432-440, 2017.

MCDONALD, P.; HENDERSON, A.R.; HERON, S.J. Biochemistry of silage. 2.ed. Marlow: Chalcombe. 340p, 1991.

MUCK, R.E. Factors influencing silage quality and their implications for management. Journal of Dairy

Science, v.71, n.11, p.2992-3002, 1988.

MUCK, R. E. Silage microbiology and its control through additives. Revista Brasileira de Zootecnia, v.39, p.183191, 2010.

NOCEK, J.E. In situ and other methods to estimate ruminal protein and energy digestibility: a review. Journal of Dairy Science, v.71, n.8, p.2051-2069, 1988.

ORSKOV, E.R.; \& MCDONALD, I. The estimation of protein degradability in the rumen from incubation measurements weighed according torate of passage. Journal Agricultural Science, v. 92, p. 499 - 503, 1979.

PEDROSO, A. F.; RODRIGUES, A. A.; BARIONI JÚNIOR, W.; BARBOSA, P. F.; SANTOS, F. A. P.; NUSSIO, L. G. Aditivos químicos e inoculante bacteriano na ensilagem de cana-de-açúcar: efeitos sobre a fermentação das silagens e o desempenho de garrotes. Revista
Brasileira de Zootecnia, v.40, n.6, p.1181-1187, 2011.

ROCHA, W.J.; ROCHA JÚNIOR, V.R.; REIS, S.T.; PALMA, M.N.N.; OLIVEIRA, L. M. Cinética de fermentação ruminal da matéria seca e dos carboidratos de silagens de cana-deaçúcar com aditivos. Revista Caatinga, v. 28, n. 1, p. $228-238,2015$.

SCHMIDT, P.; NUSSIO, L. G.; QUEIROZ, O. C. M.; SANTOS, M. C.; ZOPOLLATTO, M.; TOLEDO FILHO, S. G. D.; DANIEL, J. L. P. Effects of Lactobacillus buchneri on the nutritive value of sugarcane silage for finishing beef bulls. Revista Brasileira de Zootecnia, v. 43, n. 1, p. 8-13, 2014.

SCHMIDT, P.; ROSSI JUNIOR, P.; JUNGES, D.; DIAS, L.T.; ALMEIDA, R.; MARI, L.J. Novos aditivos microbianos na ensilagem da cana-deaçúcar: composição bromatológica, perdas fermentativas, componentes voláteis e estabilidade aeróbia. Revista Brasileira de Zootecnia, v.40, n.3, p.543-549, 2011.

SAMPAIO, I.B.M.. Experimental designs and modeling techniques in the study of roughage degradation in rumen and growth of ruminants. Reading: University of Reading, 1988. 214p. Tese (Doutorado) - University of Reading, 1988.

SIQUEIRA, G.R.; REIS, R.A.; SCHOCKEN-ITURRINO, R.P.; ROTH, A.P.T.P.; ROTH, M.T.P.; RESENDE, F.D. Perfil fermentativo de silagens de cana-de-açúcar in natura ou queimada e tratadas ou não com Lactobacillus buchneri. Revista Brasileira de Zootecnia, v.40, n.8, p.1651-1661, 2011. 
SILVA, D.J.; QUEIROZ, A.C. Análise de alimentos: métodos químicos e biológicos. 3.ed., Viçosa: UFV, 2002. $235 \mathrm{p}$.

TOMICH, T.R. \& SAMPAIO, I.B.M. A new strategy for the determination of forage degradability with an in situ technique through the use of one fistulated ruminant. Journal Agricultural Science, v.142, p.589593, 2004.

VALERIANO, A.R.; PINTO, J.C.; ÁVILA, C.L.S.; EVANGELISTA, A.R.; TAVARES, V. B.; SCHWAN, R. F. Efeito da adição de Lactobacillus sp. na ensilagem de cana-de-açúcar.

Revista Brasileira de Zootecnia, v.38, n.6, p.1009-1017, 2009.

VAN SOEST, P.J., MASON, V.C. The influence of the Maillard reaction upon the nutritive value of fibrous feeds. Animal Feed Science and Technology. v. 32, p. 45-53, 1991. 